pp. $39-47$

\title{
Global Transformation as a Strategic Marketing Factor of Effective Management of Regional Foreign Economic Relations in Modern Conditions
}

Submitted 06/05/20, 1st revision 02/06/20, 2nd revision 15/07/20, accepted 30/07/20

\author{
T.S. Malakhova ${ }^{1}$, M.Ya. Veprikova $^{2}$, A.A. Kovalenko ${ }^{3}$, E.E. Udovik ${ }^{4}$ \\ Abstract:
}

Purpose: This article aims to study and evaluate the foreign trade relations and marketing interactions of the EU countries, to identify problems and contradictions between partner countries in foreign trade.

Design/Methodology/Approach: Foreign trade relations between developed and developing EU countries are becoming increasingly contradictory and complex. On this basis, the authors revealed a modern negative trend. It is the increasing import dependence of Central-Eastern Europe and South countries on foreign companies and organizations. This trend may be resulted in the degradation of key industries in developing EU countries. As a theoretical and methodological basis, authors use historical-logical, statistical and comparative analysis and the method of scientific abstraction.

Findings: The proposed mechanism "consolidation of industry clusters" can be applied in the $E U$. Based on the identified problems and contradictions in the framework of integration, this mechanism will help to smooth out economic inequality between the EU countries.

Practical implications: In practice, the authors talk about the consistent application of the foreign economic relations mechanism between countries within the framework of the integration group. This mechanism will allow to focus on the industry specialization of the partner countries in the association and allow the periphery countries to become active participants in the European market.

Originality/value: Economic inequality between developed and developing countries of the $E U$ affects foreign trade relations between partner countries, which can lead to the transformation of the integration group in the short and medium term.

Keywords: EU, foreign trade relations, economic inequality and sovereignty, global crisis.

JEL Codes: F02, F15, F63.

Paper type: Research article.

\footnotetext{
${ }^{1}$ Ph.D., in Economics, Associate Professor of the World Economy and Management Department, Kuban State University, Krasnodar; Applicant for Doctor's Degree of the World Economy Department, Plekhanov Russian University of Economics, Moscow, Russian Federation, e-mail: malakhovats@mail.ru

${ }^{2}$ Ph.D., in Economics, Associate Professor of the Department of Economy and Management, Russian University of Economics named after G.V. Plekhanov (Krasnodar branch), Krasnodar, Russian Federation, e-mail: veprikova@mail.ru

${ }^{3}$ Applicant of the Management and Marketing Department, Belgorod State University, Belgorod, Russian Federation, e-mail: kovalenko@mail.ru

${ }^{4}$ D.Sc., in Pedagogy, Ph.D., in Economics, Professor of the Economy and Management Department, Kuban State University of Technology, Krasnodar, e-mail: udovik@mail.ru
} 


\section{Introduction}

European Union's foreign trade relations with some countries and regions are changing under the world geo-economic imbalance influence. In addition, trade and economic relations between partner countries are also significantly transformed within the framework of the Association. This trend became especially active after the first wave of the global economic crisis (2008-2011), the sanctions regime, etc. The expert community highlighted the countries of "risk groups" after the crisis. These countries cannot reach the growth trajectory of their economy. First of all, we are talking about the countries of Southern and Central-Eastern Europe within the European Union. Based on the economic inequality between developed and developing countries in the EU, there is a confrontation between companies from Central and Eastern Europe, Southern countries and Western European multinational corporations in the common market of the European region.

Such confrontations lead to the budget deficit, state debt accumulation, growth of unemployment, the sectoral structure degradation of certain peripheral countries in the European Union, etc. When joining the integration group, the countries of Central Eastern Europe and the South expected foreign investment to their economies from Western European partners in the integration group. However, this did not happen on the scale that these countries had hoped for. After all, according to world practice, the largest TNCs invest funds only to highly profitable industries. It should be noted that TNCs have one goal. To get super-profits from their activity as soon as possible. But not all the sectors of the peripheral countries are attractive for investment.

\section{Materials and Methods}

In accordance with new forms and mechanisms in foreign economic relations between countries, strategies for their medium- and long-term relations are being developed. Outstanding economists and experts try to evaluate and make forecasting on foreign trade and economic relations between countries. They are Reidy (1966), Wishlade, Taylor and Yuell (1998), Peng (2007), Balassa (1982), Galbraith (1951), Jovanovic (2003), Prebisch (1981), Myrdal (1956), Tinbergen (1952), Nehru (1961), Gasol Sanchez (1966), Pasos (1953), Frank (1980), Williams (1953), and Winer (1953).

The process-system approach used for the main indicators analysis of the EU countries foreign trade and identifying the features of foreign trade relations between the countries is an important argument to implement the mechanism "consolidation of industry clusters".

\section{Results}

Based on the above problems, we can analyse data in Table 1, indicating the main features of the EU countries' foreign trade such as export, import, foreign trade 
turnover, foreign trade balance. The foreign trade balance is one of the most important features of any state's foreign trade activity. It must be admitted that during this period, $16 \mathrm{EU}$ countries from 28 ones have negative balance. In general, the negative foreign trade balance means that the cost of imported goods is higher than the cost of exported goods. Also, it means that there is little demand for goods and services in the world and regional markets. During the analysed period, the active trade balance was registered only in Belgium, the Czech Republic, Denmark, Germany, Hungary, Ireland, Italy, the Netherlands, Poland, Slovakia, and Slovenia.

Table 1. The main indicators of the EU countries foreign trade for 2014-2017, (billion euro) (CIS\&EU, 2018; Eurostat, 2018; Ereport, 2020]

\begin{tabular}{|c|c|c|c|c|c|c|c|c|c|c|c|c|}
\hline $\begin{array}{l}\text { States- } \\
\text { members } \\
\text { of the } \\
\text { European } \\
\text { Union }\end{array}$ & $\begin{array}{l}\text { Expor } \\
t / \\
\text { Impor } \\
t \\
2014\end{array}$ & \begin{tabular}{|l|} 
Foreig \\
$\mathrm{n}$ trade \\
turnov \\
er, \\
2014
\end{tabular} & $\begin{array}{l}\text { Balanc } \\
\text { e, } \\
2014\end{array}$ & $\begin{array}{l}\text { Expor } \\
\text { t/ } \\
\text { Impor } \\
\text { t } \\
2015 \\
\Gamma .\end{array}$ & 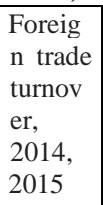 & $\begin{array}{l}\text { Balanc } \\
\text { e, } \\
2015\end{array}$ & $\begin{array}{l}\text { Expor } \\
t / \\
\text { Impor } \\
t \\
2016\end{array}$ & \begin{tabular}{|l|} 
Foreig \\
$\mathrm{n}$ trade \\
turnov \\
er, \\
2016
\end{tabular} & $\begin{array}{l}\text { Balanc } \\
\text { e, } \\
2016\end{array}$ & $\begin{array}{l}\text { Expor } \\
t / \\
\text { Impor } \\
t \\
2017\end{array}$ & $\begin{array}{l}\text { Foreig } \\
\mathrm{n} \text { trade } \\
\text { turnov } \\
\text { er, } \\
2017\end{array}$ & $\begin{array}{l}\text { Balanc } \\
\text { e, } \\
2017\end{array}$ \\
\hline Austria & $\begin{array}{l}134,2 \\
/ \\
137,0\end{array}$ & 271,2 & $-2,8$ & $\begin{array}{l}137,8 \\
/ \\
140,7\end{array}$ & 278,5 & $-2,9$ & $\begin{array}{l}137,4 \\
/ \\
142,5\end{array}$ & 279,9 & $-5,1$ & $\begin{array}{l}148,8 \\
/ \\
155,6\end{array}$ & 304,4 & $-6,8$ \\
\hline Belgium & $\begin{array}{l}355,3 \\
/ \\
341,4\end{array}$ & 696,7 & 13,9 & $\begin{array}{l}357,8 \\
/ \\
338,6\end{array}$ & 696,4 & 19,2 & $\begin{array}{l}359,5 \\
/ \\
342,5\end{array}$ & 702,0 & 17,0 & $\begin{array}{l}381,0 \\
/ \\
360,2\end{array}$ & 741,2 & 20,8 \\
\hline Bulgaria & $\begin{array}{l}22,0 / \\
26,1 \\
\end{array}$ & 48,1 & $-4,1$ & $\begin{array}{l}22,9 / \\
26,3\end{array}$ & 49,2 & $-3,4$ & $\begin{array}{l}24,0 / \\
26,2 \\
\end{array}$ & 50,2 & $-2,2$ & $\begin{array}{l}26,6 / \\
30,2 \\
\end{array}$ & 56,8 & $-3,6$ \\
\hline Hungary & $\begin{array}{l}83,3 / \\
79,0\end{array}$ & 162,3 & 4,3 & $\begin{array}{l}88,8 / \\
82,9\end{array}$ & 171,7 & 5,9 & $\begin{array}{l}92,1 / \\
84,8\end{array}$ & 176,9 & 7,3 & $\begin{array}{l}100,6 \\
/ \\
95,0\end{array}$ & 195,6 & 5,6 \\
\hline Germany & $\begin{array}{l}1125, \\
0 / \\
908,6\end{array}$ & 2033,6 & 216,4 & $\begin{array}{l}1195, \\
8 / \\
947,6\end{array}$ & 2143,4 & 248,2 & $\begin{array}{l}1205, \\
5 / \\
953,8\end{array}$ & 2159,3 & 251,7 & $\begin{array}{l}1281, \\
9 / \\
1033, \\
1 \\
\end{array}$ & 2315,0 & 248,8 \\
\hline Greece & $\begin{array}{l}27,1 / \\
48,3\end{array}$ & 75,4 & $-21,2$ & $\begin{array}{l}25,9 / \\
43,6\end{array}$ & 69,5 & $-17,7$ & $\begin{array}{l}25,5 / \\
44,2\end{array}$ & 69,7 & $-18,7$ & $\begin{array}{l}28,9 / \\
50,3\end{array}$ & 79,2 & $-21,4$ \\
\hline Denmark & $\begin{array}{l}83,9 / \\
75,0 \\
\end{array}$ & 158,9 & 8,9 & $\begin{array}{l}86,1 / \\
77,2\end{array}$ & 163,3 & 8,9 & $\begin{array}{l}86,1 / \\
77,3\end{array}$ & 163,4 & 8,8 & $\begin{array}{l}90,8 / \\
82,3\end{array}$ & 173,1 & 8,5 \\
\hline Ireland & $\begin{array}{l}91,2 / \\
61,8\end{array}$ & 153,0 & 29,4 & $\begin{array}{l}111,3 \\
/ \\
69,5 \\
\end{array}$ & 180,8 & 41,8 & $\begin{array}{l}118,2 \\
/ \\
73,3 \\
\end{array}$ & 191,5 & 44,9 & $\begin{array}{l}121,4 \\
/ \\
78,1\end{array}$ & 199,5 & 43,3 \\
\hline Spain & $\begin{array}{l}244,3 \\
/ \\
270,2\end{array}$ & 514,5 & $-25,9$ & $\begin{array}{l}254,6 \\
/ \\
281,2\end{array}$ & 535,8 & $-26,6$ & $\begin{array}{l}262,0 \\
/ \\
281,1\end{array}$ & 543,1 & $-19,1$ & $\begin{array}{l}283,7 \\
/ \\
310,4\end{array}$ & 594,1 & $-26,7$ \\
\hline Italy & $\begin{array}{l}398,9 \\
/ \\
356,9\end{array}$ & 755,8 & 42,0 & $\begin{array}{l}412,3 \\
/ \\
370,5\end{array}$ & 782,8 & 41,8 & $\begin{array}{l}417,3 \\
/ \\
367,6\end{array}$ & 784,9 & 49,7 & $\begin{array}{l}448,1 \\
/ \\
400,7\end{array}$ & 848,8 & 47,4 \\
\hline Cyprus & $\begin{array}{l}2,4 / \\
6,0 \\
\end{array}$ & 8,4 & $-3,6$ & $\begin{array}{l}3,0 / \\
6,3 \\
\end{array}$ & 9,3 & $-3,3$ & $\begin{array}{l}2,7 / \\
7,1 \\
\end{array}$ & 9,8 & $-4,4$ & $\begin{array}{l}2,9 / \\
8,1 \\
\end{array}$ & 11,0 & $-5,2$ \\
\hline Latvia & $\begin{array}{l}11,0 / \\
13,3\end{array}$ & 24,3 & $-2,3$ & $\begin{array}{l}10,9 / \\
13,1\end{array}$ & 24,0 & $-2,2$ & $\begin{array}{l}11,0 / \\
12,9\end{array}$ & 23,9 & $-1,9$ & $\begin{array}{l}12,3 / \\
14,9 \\
\end{array}$ & 27,2 & $-2,6$ \\
\hline Lithuania & $\begin{array}{l}24,4 / \\
25,9 \\
\end{array}$ & 50,3 & $-1,5$ & $\begin{array}{l}22,9 / \\
25,4\end{array}$ & 48,3 & $-2,5$ & $\begin{array}{l}22,6 / \\
24,7 \\
\end{array}$ & 47,3 & $-2,1$ & $\begin{array}{l}26,4 / \\
28,5 \\
\end{array}$ & 54,9 & $-2,1$ \\
\hline $\begin{array}{l}\text { Luxembo } \\
\text { urg }\end{array}$ & $\begin{array}{l}14,4 / \\
20,1 \\
\end{array}$ & 34,5 & $-5,7$ & $\begin{array}{l}15,5 / \\
21,0\end{array}$ & 36,5 & $-5,5$ & $\begin{array}{l}14,3 / \\
19,7 \\
\end{array}$ & 34,0 & $-5,4$ & $\begin{array}{l}14,0 / \\
20,1\end{array}$ & 34,1 & $-6,1$ \\
\hline Malta & $\begin{array}{l}2,2 / \\
5,1\end{array}$ & 7,3 & $-2,9$ & $\begin{array}{l}2,4 / \\
5,4\end{array}$ & 7,8 & $-3,0$ & $\begin{array}{l}2,8 / \\
5,8 \\
\end{array}$ & 8,6 & $-3,0$ & $\begin{array}{l}2,2 / \\
5,1\end{array}$ & 7,3 & $-2,9$ \\
\hline
\end{tabular}


Global Transformation as a Strategic Marketing Factor of Effective Management of Regional Foreign Economic Relations in Modern Conditions

\begin{tabular}{|c|c|c|c|c|c|c|c|c|c|c|c|c|}
\hline $\begin{array}{l}\text { Netherlan } \\
\text { ds }\end{array}$ & $\begin{array}{l}506,3 \\
/ \\
443,7 \\
\end{array}$ & 950,0 & 62,6 & $\begin{array}{l}514,3 \\
/ \\
461,8\end{array}$ & 976,1 & 52,5 & $\begin{array}{l}516,2 \\
/ \\
456,3\end{array}$ & 972,5 & 59,9 & $\begin{array}{l}576,6 \\
/ \\
508,7 \\
\end{array}$ & 1085,3 & 67,9 \\
\hline Poland & $\begin{array}{l}165,7 \\
/ \\
168,4\end{array}$ & 334,1 & $-2,7$ & $\begin{array}{l}179,5 \\
/ \\
177,2\end{array}$ & 356,7 & 2,3 & $\begin{array}{l}184,2 \\
/ \\
180,3\end{array}$ & 364,5 & 3,9 & $\begin{array}{l}204,4 \\
/ \\
204,0\end{array}$ & 408,4 & 0,4 \\
\hline Portugal & $\begin{array}{l}48,1 / \\
59,0\end{array}$ & 107,1 & $-10,9$ & $\begin{array}{l}49,6 / \\
60,3\end{array}$ & 109,9 & $-10,7$ & $\begin{array}{l}50,0 / \\
61,4\end{array}$ & 111,4 & $-11,4$ & $\begin{array}{l}55,1 / \\
69,0 \\
\end{array}$ & 124,1 & $-13,9$ \\
\hline Romania & $\begin{array}{l}52,5 / \\
58,6\end{array}$ & 111,1 & $-6,1$ & $\begin{array}{l}54,6 / \\
63,0\end{array}$ & 117,6 & $-8,4$ & $\begin{array}{l}57,4 / \\
67,4\end{array}$ & 124,8 & $-10,0$ & $\begin{array}{l}62,6 / \\
75,6\end{array}$ & 138,2 & $-13,0$ \\
\hline Slovakia & $\begin{array}{l}65,1 / \\
61,7 \\
\end{array}$ & 126,8 & 3,4 & $\begin{array}{l}67,8 / \\
66,2 \\
\end{array}$ & 134,0 & 1,6 & $\begin{array}{l}70,1 / \\
68,2\end{array}$ & 138,3 & 1,9 & $\begin{array}{l}74,8 / \\
73,7 \\
\end{array}$ & 148,5 & 1,1 \\
\hline Slovenia & $\begin{array}{l}27,1 / \\
25,6\end{array}$ & 52,7 & 1,5 & $\begin{array}{l}28,8 / \\
26,9\end{array}$ & 55,7 & 1,9 & $\begin{array}{l}29,7 / \\
27,6\end{array}$ & 57,3 & 2,1 & $\begin{array}{l}34,0 / \\
31,9\end{array}$ & 65,9 & 2,1 \\
\hline $\begin{array}{l}\text { Great } \\
\text { Britain }\end{array}$ & $\begin{array}{l}380,3 \\
/ \\
519,7\end{array}$ & 900,0 & $-139,4$ & $\begin{array}{l}414,7 \\
/ \\
564,6\end{array}$ & 979,3 & $-149,9$ & $\begin{array}{l}370,0 \\
/ \\
574,9\end{array}$ & 944,9 & $-204,9$ & $\begin{array}{l}390,8 \\
/ \\
570,1\end{array}$ & 960,9 & $-179,3$ \\
\hline Finland & $\begin{array}{l}56,0 / \\
57,8\end{array}$ & 113,8 & $-1,8$ & $\begin{array}{l}54,0 / \\
54,5\end{array}$ & 108,5 & $-0,5$ & $\begin{array}{l}52,3 / \\
55,0\end{array}$ & 107,3 & $-2,7$ & $\begin{array}{l}60,2 / \\
62,4\end{array}$ & 122,6 & $-2,2$ \\
\hline France & $\begin{array}{l}437,4 \\
/ \\
510,9 \\
\end{array}$ & 948,3 & $-73,5$ & $\begin{array}{l}456,4 \\
/ \\
516,8 \\
\end{array}$ & 973,2 & $-60,4$ & $\begin{array}{l}453,3 \\
/ \\
517,0 \\
\end{array}$ & 970,3 & $-63,7$ & $\begin{array}{l}473,6 \\
/ \\
552,8 \\
\end{array}$ & 1026,4 & $-79,2$ \\
\hline Croatia & $\begin{array}{l}10,4 / \\
17,2\end{array}$ & 27,6 & $-6,8$ & $\begin{array}{l}11,7 / \\
18,6\end{array}$ & 30,3 & $-6,9$ & $\begin{array}{l}12,5 / \\
19,8\end{array}$ & 32,3 & $-7,3$ & $\begin{array}{l}14,2 / \\
22,0\end{array}$ & 36,2 & $-7,8$ \\
\hline Czech & $\begin{array}{l}131,8 \\
/ \\
116,2 \\
\end{array}$ & 248,0 & 15,6 & $\begin{array}{l}142,4 \\
/ \\
127,5\end{array}$ & 269,9 & 14,9 & $\begin{array}{l}147,0 \\
/ \\
129,3\end{array}$ & 276,3 & 17,7 & $\begin{array}{l}159,5 \\
/ \\
143,4\end{array}$ & 302,9 & 16,1 \\
\hline Sweden & $\begin{array}{l}123,9 \\
/ \\
122,1 \\
\end{array}$ & 246,0 & 1,8 & $\begin{array}{l}126,3 \\
/ \\
124,8 \\
\end{array}$ & 251,1 & 1,5 & $\begin{array}{l}126,0 \\
/ \\
127,2 \\
\end{array}$ & 253,2 & $-1,2$ & $\begin{array}{l}135,5 \\
/ \\
136,3 \\
\end{array}$ & 271,8 & $-0,8$ \\
\hline Estonia & $\begin{array}{l}12,1 / \\
13,8\end{array}$ & 25,9 & $-1,7$ & $\begin{array}{l}11,6 / \\
13,1\end{array}$ & 24,7 & $-1,5$ & $\begin{array}{l}11,9 / \\
13,5\end{array}$ & 25,4 & $-1,6$ & $\begin{array}{l}12,9 / \\
14,7\end{array}$ & 27,6 & $-1,8$ \\
\hline
\end{tabular}

Source: Authors.

Year 2017 was especially successful for the Netherlands. The foreign trade balance was 67.9 billion euros which was $7.8 \%$ more than in 2014. The economy of Belgium is especially important for the analysis. In 2017, export from the country was 381.0 billion euros, while import was 360.2 billion euros. At the end of 2017, the foreign trade balance turned out to be positive (20.8 billion euros). In comparison with 2014 (export from the country amounted to 355.3 billion euros) in 2017, export increased by 25.7 billion euros. The positive foreign trade balance holds also in Germany. Compared to 2014, it increased from 216.4 billion euros to 248.8 billion euros in 2017 (by $13 \%$ ). It should be noted that export from Germany despite international trade conflicts in 2018 reached a new record level. In 2018, the cost of goods exported by German enterprises was almost 1318.0 trillion euros. In 2017, export from Germany was 1281.9 trillion euros. Import on the contrary decreased from 1033.1 trillion euros in 2017 to 1090.0 trillion euros in 2018. In general, analysing the period from 2014 to 2017, we can say that export from Germany increased by 156.9 billion euros. As for import, it also increased from 908.6 billion euros in 2014 to 1033.1 trillion euros in 2017. According to data of 2018 the foreign trade surplus, for which Germany is so widely criticized in the world, decreased from 248.8 to 227.8 billion euros for a year. 
However, there are countries in the EU with negative foreign trade balance since 2014. According to our calculations, by the end of 2020, there will be more than 15 such countries. According to data presented in Table 1, many of them have more imports than exports every year, which negatively affects the sectorial structure of their economies. These are mainly countries of Southern and Central-Eastern Europe as Bulgaria, Greece, Spain, Cyprus, Latvia, Lithuania, Malta, Portugal, Romania, Croatia, and Estonia. If you examine their key sectors in the economy, you will find that sectors related to industry, agriculture, and services (mainly tourism and hospitality, etc.) are dominant in the above-mentioned countries. In addition, these countries do not have large corporations to compete with Western European countries.

The Greek economy has a lot of problems. In 2017, exports from this country amounted to 28.9 billion euros, and imports amounted to 50.3 billion euros. This situation is practically unchanged. Thus, in 2014 , exports from this country amounted to 27.1 billion euros, and import amounted to 48.3 billion euros.

The Spanish and Portuguese economies also have negative trade balances. Thus, in 2017, export from Spain amounted to 283.7 billion euros, and import amounted to 310.4 billion euros. The foreign trade balance was -26.7 billion euros. In general, this indicator has not been practically changed since 2014 . Thus, the foreign trade balance in 2014 amounted to -25.9 billion euros, in 2015 it amounted to -26.6 billion euros, in 2016 it amounted to -19.1 billion euros.

In Portugal, there is also an increase in imports over export. From 2014 to 2017, the foreign trade balance was -10.9 billion euros, -10.7 billion euros, -11.4 billion euros, and -13.9 billion euros. Many Central and Eastern European countries also have negative foreign trade balance such as Bulgaria, Estonia, Latvia, Lithuania, Romania, Estonia. For example, in 2017, export from Bulgaria amounted to 26.6 billion euros, and import amounted to 30.2 billion euros. The foreign trade balance was -3.6 billion euros. In 2014, the foreign trade balance was -4.1 billion euros, in 2015 it was -3.4, in 2016 it was -2.2 billion euros, in 2017 it was -3.6. Almost the same situation is in Latvia and Lithuania. In 2017 import to Latvia increased by 1.6 billion euros compared to 2014. In Lithuania, this figure increased by 2.6 billion euros.

Also, in Romania and Estonia, there is a tendency to import dependence on foreign goods, which leads to the degradation of national industries. The country's long-term negative balance negatively affects the national economy as a whole. Gradually some CEE countries have recently lost key industries in their country. This raises the question of preserving their sovereignty in the economic sphere. In general, enterprises, especially in Bulgaria and Romania, meet their domestic demand, and as current practice shows, they are not active players in the EU, as well as competitors for the largest Western European TNCs. In this situation, we are not even talking about any competition between these countries and TNCs of Western European countries since they were not able to fully engage in this fight. 
Therefore, there is no equal opportunities between developed and developing countries today. It is clear that foreign investors use the territory of the CEE countries and some countries of the South mainly for building plants with low or medium productivity.

Figure 1. The formation of the foreign economic relations between the European Union countries - "consolidation of industry clusters" (compiled by the authors)

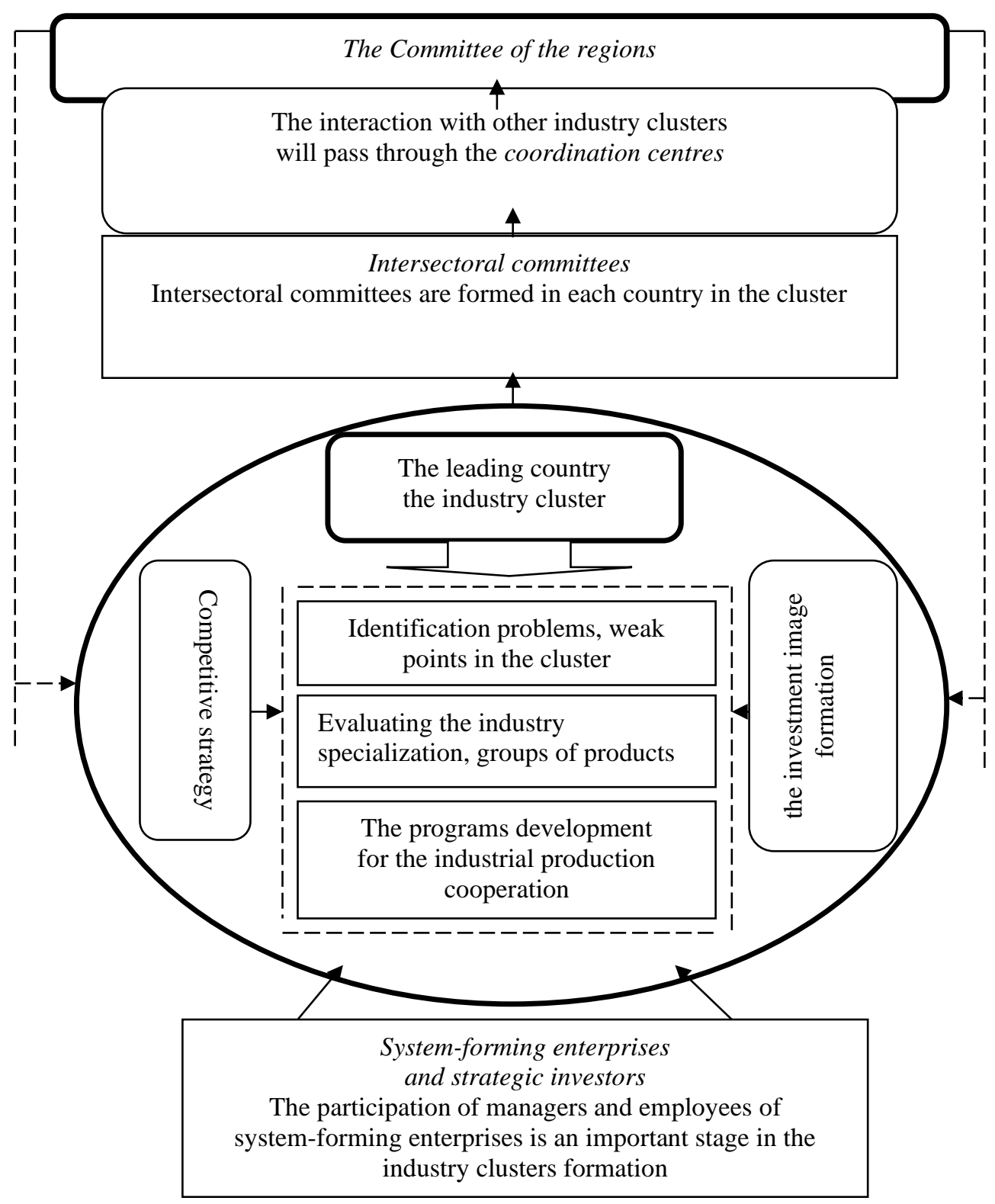

Source: Authors. 
The opposite (positive) effect was received by TNCs of developed countries, especially Germany, France, Austria, and Sweden. They were able as soon as possible not only to be adapted to the new markets of the CEE countries, to carry out extensive expansion through their subsidiaries, branches, representative offices, but also they were able to displace, and in some cases to absorb, local producers. In other words, their TNCs have formed a solid network of their own structures, and it will be quite difficult for the national economies of separate countries to break them.

In order to reduce the gap between the developed and developing countries of the EU, we propose the mechanism "consolidation of industry clusters" for foreign economic relations between countries. Figure 1 shows a model for the formation of this mechanism in the countries of the integration group. We propose in the EU to form four industry clusters with the following leading countries: the first cluster is Germany and France; the second cluster the leading country is Italy; the third cluster the leading countries are Poland and the Czech Republic, and the fourth cluster the leading country is Sweden. Figure 1 shows an example of a single industry cluster. The key subjects of this mechanism are: the Committee of regions as an Advisory body of the European Union, Coordinating centres, Intersectoral committees, leading countries in the industry clusters, countries taking part in the industry clusters, system-forming enterprises and strategic investors.

The important entity that should participate in the implementation of this mechanism is the system-forming enterprises and strategic investors. Without their active participation, it is impossible to form a whole picture of the situation that is happening in any industry of a particular country. Therefore, we integrated these subjects into this mechanism, as one of the most key ones in identifying problems at the enterprises of the EU countries themselves. On the base of identified problems and contradictions today in this integration group, we can make a conclusion that it is impossible to do without this mechanism. Today, the countries of Central and Eastern Europe, except some countries (Poland, the Czech Republic and partially Hungary), are on the sidelines of the technological development of their industries. The financial help that they received during the first wave of the global crisis from the vanguard countries and the ECB is only anti-crisis measures to smooth out the crisis phenomena in their countries. In our work, we focus on the driving forces and missed opportunities that the countries of Central and Eastern Europe can get in the integration group.

\section{Discussion}

As for the transformation of the European Union, we think about the way of its formation and development, how difficult it was to unite the countries and how long their reunification was. According to many scientists and experts, if the European Union is transformed, it will be quite difficult for small countries to resist major players not only in the European region, but also in the world market. On the base of key indicators in the European Union countries foreign trade and identified problems in 
the countries of the South and Central-Eastern Europe functioning in the European Union, we propose to apply the mechanism of foreign economic relations between the countries. It is the mechanism of "consolidation of industry clusters". Therefore, we spread our forces throughout the European Union and make it possible for centres (leaders) of the industry cluster to promote their progressive ideas in the European region.

\section{Conclusion}

Thus, according to the analysis in more than 15 countries of the European Union, the foreign trade balance is negative. First of all, it is negative in the countries of Southern and CentralEastern Europe. As for the developed countries of the European Union, most of them, especially Germany and France, benefit from interaction with peripheral countries. Transnational corporations in Western European countries were able to form a strong network of subsidiaries, branches, and representative offices throughout the European region. Because of this, peripheral countries cannot compete both in the European region and in the world market. The study shows that economic inequality between partner countries is increasing in the EU. Of course, it is necessary to solve this problem as soon as possible, since the countries of the South and CEE seek to be active participants in foreign trade and economic relations with Western European countries. The authors propose to apply the "consolidation of industry clusters" mechanism.

\section{References:}

Balassa B. 1982. The Theory of Economic Integration. Greenwood Press.

CIS\&EU. 2018. Foreign Trade of the CIS and EU countries. Pocketbook, Interstate Statistical Committee of the CIS.

Ereport. 2020. World Economy Figures. Available at: http://www.ereport.ru/stat.php?razdel=country

Eurostat. 2020. European statistics. Available at: http://ec.europa.eu/eurostat/publications/statistical-books

Frank, A.G. 1980. Crisis in the world economy. Holmes \& Meier Publishers.

Galbraith, J.K. 1951. Conditions for Economic Change in Underdeveloped Countries. American Journal of Agricultural Economics, Agricultural and Applied Economics Association, 33(4P2), 689-696.

Gazol Sanchez, A. 1966. Industrial complementation and economic integration; (the case of the A.L.A.L.C.). Libros SELA, Mexico.

Jovanović, M. 2003. European economic integration. London, London and New York publ.. Malakhova, T.S. 2015. The crisis of the global economy: trends and contradictions. Krasnodar, Kuban State University, 79-80.

Malakhova, T.S., Dubinina, M.A., Maksaev, A.A, Fomin, R.V. 2019. Foreign Trade and Marketing Processes in the Context of Sustainable Development. International Journal of Economics and Business Administration, International Strategic Management Association, S2, 2019.

Malakhova, T.S., Kolesnikov N.P. 2019. Trends and contradictions of the global economy crisis and transformation of the world financial institutions. European Journal of Economics and Management Sciences, 1, 38-41. 
Myrdal, G. 1956. An International Economy: Problems and Prospects. Harper\&brothers publishers, New York.

Nehru, J. 1961. Strategy of the Third Plan. Problems in the Third Plan - A Critical Miscelany. Delhi.

Pazos, F. 1953. Economic Development and Financial Stability. Staff Papers, International Monetary Fund, October.

Prebish, R. 1981. Peripheral capitalism: crisis and transformation. Mexico.

Reidy J. 1966. Strategy for the Americas. New York.

Tinbergen, J. 1952. On the Theory of Economic Integration. Les Cahiers de Bruges (Brugges Quarterly).

Williams, J.H. 1953. Economic Stability in a Changing World. Oxford University Press.

Winer, J. 1953. International Trade and Economic Development. Oxford, Clarendon Press, 7.

Wishlade, F., Yuill, D., Taylor, S. 1998. Economic and Social Cohesion in European Union: The Impact of Member States' Own Policies. Regional Development Studies, 29.

Yuan Peng. 2007. A harmonious world and China's new diplomacy. Contemporary International Relations. 3(17). 